\title{
Self-compatibility in 'Zaohong' Japanese apricot is associated with the loss of function of pollen $S$ genes
}

\author{
Pei-Pei Wang $\cdot$ Zhi-Hong Gao $\cdot$ Zhao-Jun Ni $\cdot$ \\ Zhen Zhang $\cdot$ Bin-Hua Cai
}

Received: 12 November 2012/Accepted: 14 September 2013/Published online: 24 September 2013

(C) The Author(s) 2013. This article is published with open access at Springerlink.com

\begin{abstract}
While most Japanese apricot (Prunus mume Sieb. et Zucc.) cultivars display typical S-RNase-based gametophytic self-incompatibility, some self-compatible (SC) cultivars have also been identified. In this study, we confirmed SC of 'Zaohong' through replicated self-pollination tests. Cross-pollination tests showed that SC of 'Zaohong' was caused by a loss of pollen function, so we determined that the $S$-genotype of 'Zaohong' was $S_{2} S_{15}$. Sequence analysis of the $S$-haplotypes of 'Zaohong' showed no mutations which were likely to alter gene function. Furthermore, expression analysis based on RTPCR of $S$-locus genes revealed no differences at the transcript level when compared with 'Xiyeqing', a selfincompatible cultivar with the same $S$ haplotypes. In addition, except for $S$-locus genes, a new type of F-box gene encoding a previously uncharacterised protein with high sequence similarity (61.03-64.65\%) to Prunus SFB genes was identified. Putative structural regions of $P m F$ box genes have been described, corresponding to regions in $P m S F B$ alleles, but with some sequence variations. These results suggest that $\mathrm{SC}$ in 'Zaohong' occurs in pollen, and that other factors outside the $S$-locus, including PmF-box genes, might be associated with the loss of function of pollen $S$ genes.
\end{abstract}

Pei-Pei Wang and Zhi-Hong Gao contributed equally to this work.

P.-P. Wang · Z.-H. Gao $(\bowtie) \cdot$ Z.-J. Ni · Z. Zhang · B.-H. Cai College of Horticulture, Nanjing Agricultural University, No.1 Weigang, Nanjing City 210095, Jiangsu Province, People's Republic of China

e-mail: 2010104021@njau.edu.cn; gaozhihong@njau.edu.cn
Keywords Japanese apricot $\cdot$ Self-compatibility (compatible) (SC) - Self-incompatibility (incompatible) (SI) $\cdot S$-RNase $\cdot S F B \cdot P m F-b o x$

\begin{tabular}{|c|c|}
\hline \\
\hline \multicolumn{2}{|c|}{ Abbreviations } \\
\hline Par & Prunus armeniaca \\
\hline$P a$ & Prunus avium \\
\hline$P d$ & Prunus dulcis \\
\hline$P s$ & Prunus salicina \\
\hline Pps & Prunus pseudocerasus \\
\hline
\end{tabular}

\section{Introduction}

The S-ribonuclease (S-RNase)-based gametophytic selfincompatibility (GSI) found in the Solanaceae [1, 2], Scrophulariaceae [3] and Rosaceae [4, 5], is a genetic mechanism in flowering plants that prevents inbreeding, promotes out-crossing, and is often controlled by the highly polymorphic, multi-allelic $S$-locus [6]. In these three families, the $S$-locus is comprised of the pistil $S$-RNase [2, 3] and the pollen-expressed SFB/SLF ( $S$-haplotype-specific F-box/S-locus F-box) genes [7-10]. Different variants of the $S$-locus are thus described as 'haplotypes'. Pollen inhibition occurs when the same $S$-haplotype is expressed in both pollen and pistil [6].

In the Solanaceae, Scrophulariaceae, and Rosaceae, active $S$-RNases expressed in the style are essential for the inhibition of pollen-tube growth during the incompatibility response and are thought to act via the degradation of ribosomal RNA within the pollen tube [11]. F-box proteins meanwhile, are components of the SCF complex, which 
regulates protein degradation via the ubiquitin/26S proteasome pathway [7-15]. Therefore, the identification of $S$ linked F-box genes expressed in pollen raises the possibility that the ubiquitin/26S proteasome pathway plays a key role in self/non-self pollen discrimination in S-RNasebased GSI. The type of interaction between S-RNase and $S F B$ might determine SI or SC [16].

In most Prunus fruit trees, natural or artificially-produced self-compatible (SC) mutants have been used to study the molecular basis of the S-RNase-based GSI system, which is attributed to the loss of function of the factors at the $S$ locus [17] or external to the $S$ locus [6]. Stylar-part mutations (SPMs) at the $S$-locus have been discovered in several SC species such as peach (Prunus persica) [17], almond (Prunus dulcis) [18], sour cherry (Prunus cerasus) [19] and Japanese pear (Pyrus serotina) [5, 20], whereas pollen-part mutations (PPMs) have also been discovered in peach $(P$. persica) [17], sour cherry ( $P$. cerasus) [19], as well as in sweet cherry (Prunus avium) [12, 21, 22] and in Japanese apricot (Prunus mume) 12, 23]. SPMs and PPMs in SC mutants have mainly been found to be associated with deletions or insertions in $S$-RNase and $S F B$ genes, respectively. Finally, SC has also been associated with mutations at a modifier locus that is unlinked to the $S$-locus in various Prunus species [24-28].

The Japanese apricot, which originated in southeast China, belongs to the Rosaceae family and is an important economical and deciduous fruit crop that exhibits GSI [2931]. The fruit of Japanese apricot has always been a valuable processing material used in the food and beverage industries [32]. Since Japanese apricot exhibits GSI, pollinator cultivars are required in commercial production to ensure fruit set. However, different to other Prunus species, the Japanese apricot blooms very early in the spring, so that low temperature, wind conditions and available insects will restrict pollination. Thus, SC cultivars have a horticultural advantage over SI cultivars because no cross-pollinatorer is required, especially for the Japanese apricot [30, 31]. Therefore, it is necessary to search for different mechanisms of SC in order to avoid inbreeding depression.

In this study, we used data derived from self-pollination tests to confirm that 'Zaohong' showed SC. The objective was further to investigate the cause of this SC in 'Zaohong' through cross-pollination tests, and to analyse both $S$ $R N a s e$ and $S F B$ genes and other factors outside the $S$-locus.

\section{Materials and methods}

Plant material

'Zaohong' $\left(S_{2} S_{15}, \mathrm{SC}\right)$ [32] and Xiyeqing $\left(S_{2} S_{15}, \mathrm{SI}\right)$ [32] trees grown in the National Field Genebank for Japanese apricot cultivars located at Nanjing Agricultural University were used in this study. Young leaves, pollen grains, and styles with stigmas were collected in April 2012, frozen in liquid nitrogen, and stored at $-70{ }^{\circ} \mathrm{C}$ until use.

\section{Field pollination tests}

Self-pollination and cross-pollination tests of 'Zaohong' and 'Xiyeqing' were carried out in the field. Pollen samples were collected from flowers at the balloon stage and dried at room temperature, then stored in a desiccator at $4{ }^{\circ} \mathrm{C}$ until use. Before pollination, pollen viability was examined and the stamens were removed by forceps. Flower buds were emasculated before anthesis and covered with paper bags to avoid contamination. The number of fruits set was recorded 60 days after pollination, and fruit rate was calculated using data collected over a 3-year survey. In terms of the standard, fruit set $\geq 5 \%$ was considered to be SC, whereas that $<5 \%$ was considered to be SI [31].

\section{DNA and RNA extraction}

Total genomic DNA was extracted from frozen young leaves of 'Zaohong' using the cetyl trimethyl ammonium bromide (CTAB) method according to Wang et al. [33]. Total RNA was extracted from pollen grains, styles and leaves of 'Zaohong' and 'Xiyeqing' as described in Tao et al. [34].

\section{PCR of S-RNase alleles}

For the identification of the $S$-genotype of 'Zaohong', PCR amplification was carried out using a Prunus S-RNase consensus primer pair, Pru-C2 [34] and PCE-R [35], designed from the second and third conserved regions of Prunus S-RNase genes, respectively (Table 1). To analyse further the structure of $S$-RNase genes, $S_{2}$-RNase and $S_{15^{-}}$ RNase were amplified using the Prunus S-RNase consensus primer pair, SRc-F [36] and PM-C5 [37], designed from the signal peptide and the fifth conserved region of Prunus $S$ RNase genes, respectively (Table 1). PCR reaction mixtures and conditions were identical to those described by $\mathrm{Xu}$ et al. [38]. PCR was performed in a $25 \mu \mathrm{L}$ reaction volume containing $69 \mathrm{ng}$ genomic DNA, $2.0 \mu \mathrm{L}$ $10 \times$ PCR buffer (TaKaRa, Kyoto, Japan), $1.5 \mathrm{mM}$ $\mathrm{MgCl}_{2}, 0.15 \mathrm{mM}$ dNTPs, $0.1 \mu \mathrm{M}$ each primer and $1 \mathrm{U}$ Taq DNA polymerase (TaKaRa, Japan) in a PTC-100 thermal cycler (MJ Research, Cambridge, MA, USA). PCR reactions were run with a programme of 35 cycles at $94{ }^{\circ} \mathrm{C}$ for $30 \mathrm{~s}, 60{ }^{\circ} \mathrm{C}$ for $40 \mathrm{~s}$ and $72{ }^{\circ} \mathrm{C}$ for $90 \mathrm{~s}$, with an initial denaturation at $94{ }^{\circ} \mathrm{C}$ for 3 min and a final extension of $72{ }^{\circ} \mathrm{C}$ for $10 \mathrm{~min}$. The PCR products were separated by $1.2 \%$ agarose gel electrophoresis in $1 \times$ TAE buffer and 
Table 1 Sequences of primers used in this study

\begin{tabular}{lll}
\hline Primer & Sequence $\left(\right.$ from $5^{\prime}$ to $3^{\prime}$ ) & Notes \\
\hline ActF1 & ATGGTGAGGATATTCAACCC & {$[9]$} \\
ActR1 & CTTCCTGTGGACAATGGATGG & {$[9]$} \\
Pru-C2 & CTATGGCCAAGTAATTATTCAAACC & {$[34]$} \\
PCE-R & TGTTTGTTCCATTCGCYTTCCC & {$[35]$} \\
F-BOX5 ${ }^{\prime}$ A & TTKSCHATTRYCAACCKCAAAAG & {$[39]$} \\
SFB-C1F & RTTCGRTTTCTDTTTACRTG & {$[35]$} \\
SRc-F & CTCGCTTTCCTTGTTCTTGC & {$[36]$} \\
PM-C5 & CATAATACCACTTCATGTAA & {$[37]$} \\
Pm-Vb & ATCCAAGCAAGTTCTTGAAACA & This study \\
SFB2A & GTTCGGTTTCTATTTACGTG & This study \\
SFB2B & ATGGGTCGAAGAGATTTAGC & This study \\
SFB15A & ATGCAAGTCGTGGAGTGATT & This study \\
SFB15B & CGATAAGGGCGTAGCAGATC & This study \\
PmF1 & AAGGATAAAGAAAAGGACGC & This study \\
PmF2 & CTACGAAAACTACGAAGACT & This study \\
\hline
\end{tabular}

observed using an ultraviolet light system (FR-200, Peiqing, China).

PCR of $S F B$ alleles

PCR amplification of $S F B$ alleles in 'Zaohong' was performed using the primers, F-BOX5'A [39], SFB-C1F [40] and $\mathrm{Pm}-\mathrm{Vb}$, which were designed from conserved regions upstream from the intron, the F-box motif and upstream from $\mathrm{HVb}$ of Prunus SFB genes, respectively (Table 1). PCRs were performed in a $20 \mu \mathrm{L}$ reaction volume containing $70 \mathrm{ng}$ genomic DNA, $2.0 \mu \mathrm{L} 10 \times$ PCR buffer (TaKaRa, Kyoto, Japan), $1.5 \mathrm{mM} \mathrm{MgCl} 2,0.2 \mathrm{mM}$ dNTPs, $0.1 \mu \mathrm{M}$ of each primer and $1 \mathrm{U}$ Taq DNA polymerase (TaKaRa, Japan). PCR reactions were run with a programme of 35 cycles at $94{ }^{\circ} \mathrm{C}$ for $1 \mathrm{~min}, 56{ }^{\circ} \mathrm{C}$ for $1 \mathrm{~min}$ and $72{ }^{\circ} \mathrm{C}$ for $90 \mathrm{~s}$, with an initial denaturing at $94{ }^{\circ} \mathrm{C}$ for $3 \mathrm{~min}$ and a final extension of $72{ }^{\circ} \mathrm{C}$ for $10 \mathrm{~min}$. The PCR products were separated by $1.2 \%$ agarose gel electrophoresis in $1 \times$ TAE buffer and observed using an ultraviolet light system (FR-200, Peiqing, China).

\section{RT-PCR}

One microgram of total RNA from pollen grains, styles, and leaves was used for first-strand cDNA synthesis using a PrimeScript RT reagent Kit with gDNA Eraser (TaKaRa), with the resulting cDNAs acting as templates for RT-PCR. RT-PCRs of the S-RNase, SFB and Actin genes were performed using the primer pairs Pru-C2/PCE-R, SFB-C1F/ $\mathrm{Pm}-\mathrm{Vb}$ and $\mathrm{ActF} 1 / \mathrm{ActR} 1$, respectively (Table 1 ). In addition, the specific primer pair SFB2A and SFB2B was used for the amplification of $\mathrm{PmSFB}_{2}$, and SFB15A and
Table 2 Rates of fruit setting in self- or cross-pollination of 'Zaohong' and 'Xiyeqing'

\begin{tabular}{rrlll}
\hline$q$ & \multirow{2}{q}{} & $\begin{array}{l}\text { Number } \\
\text { of flowers } \\
\text { pollinated }\end{array}$ & $\begin{array}{l}\text { Number } \\
\text { of fruit } \\
\text { set }\end{array}$ & $\begin{array}{l}\text { Rate of } \\
\text { fruit set } \\
(\%)\end{array}$ \\
\hline $\begin{array}{r}\text { Zaohong } \\
\left(S_{2} S_{15}\right)\end{array}$ & $\begin{array}{r}\text { Zaohong } \\
\left(S_{2} S_{15}\right)\end{array}$ & 210 & 34 & 16.19 \\
$\begin{array}{r}\text { Xiyeqing } \\
\left(S_{2} S_{15}\right)\end{array}$ & $\begin{array}{r}\text { Xiyeqing } \\
\left(S_{2} S_{15}\right)\end{array}$ & 210 & 0 & 0 \\
$\begin{array}{r}\text { Zaohong } \\
\left(S_{2} S_{15}\right)\end{array}$ & $\begin{array}{r}\text { Xiyeqing } \\
\left(S_{2} S_{15}\right)\end{array}$ & 210 & 0 & 0 \\
$\begin{array}{r}\text { Xiyeqing } \\
\left(S_{2} S_{15}\right)\end{array}$ & $\begin{array}{r}\text { Zaohong } \\
\left(S_{2} S_{15}\right)\end{array}$ & 210 & 26 & 12.38 \\
\hline
\end{tabular}

SFB15B for the amplification of $P m S F B_{15}$. For the newlydescribed PmF-box genes, specific primers PmF1 and $\mathrm{PmF} 2$ were designed from conserved regions of these genes. PCR reaction mixtures and conditions used were as described for genomic DNA amplification.

Cloning and sequencing of genomic PCR products and cDNAs

All PCR products and cDNA fragments were excised from $1.2 \%$ agarose gels and purified using the Agarose Gel DNA Purification Kit (TaKaRa, Japan). The purified products were cloned into the PMD19-T vector (TaKaRa) following the manufacturer's instructions and transformed into Escherichia coli DH5 $\alpha$. Target clones were sequenced on an ABI Prism 3700 DNA analyser (ABI, 3730, USA) using the M13 primer and the Big Dye Terminator Version 3.1. To obtain accurate sequences and avoid PCR amplification errors, four positive clones of each fragment were sequenced by the Invitrogen Company (Shanghai, China).

Sequence and phylogenetic analysis

Homology searches were performed using BLAST (National Center for Biotechnology Information). Sequence alignments were performed using DNAMAN (version 5.2; Lynnon Biosoft). A phylogenetic tree was then generated using MEGA version 3.1 using P-distance and neighbour-joining methods with 1,000 bootstrap replication tests.

\section{Results}

Pollination tests

To confirm the SC/SI of 'Zaohong' and 'Xiyeqing', selfpollination tests were carried out (Table 2). For 


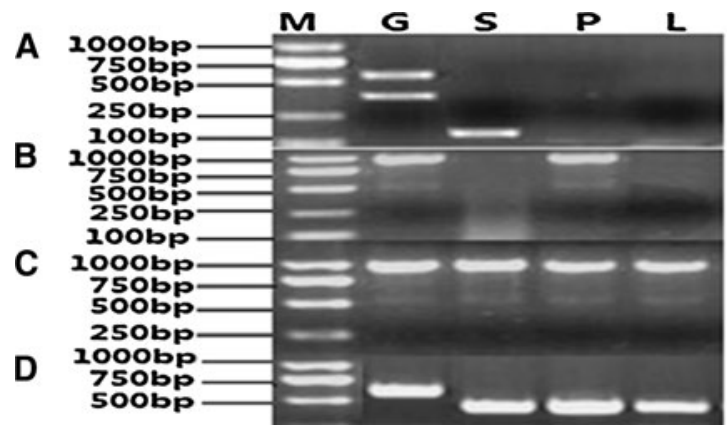

Fig. 1 PCR amplification of $S$-RNase and $S F B$ alleles from 'Zaohong' and expression analysis for PmS-RNase (a), PmSFB (b), PmFbox genes $(c)$ and Actin genes $(d)$ in pollen $(P)$, styles $(S)$, and leaves

'Zaohong' and 'Xiyeqing', the number of fruits set from 210 flower buds were 34 and 0 , respectively. According to the criteria that cultivars with a fruit set $\geq 5 \%$ showed $\mathrm{SC}$, the fruit set of $16.19 \%$ indicated that 'Zaohong' showed SC. Apparently 'Xiyeqing' with a fruit set of $0 \%$ showed SI.

In addition, 'Zaohong' was reciprocally crossed with 'Xiyeqing', a cultivar with the same $S$ haplotypes $\left(S_{2} S_{15}\right)$. As presented in Table 2, no fruits were obtained when 'Zaohong' was used as a hybrid female parent. However, the number of fruits set was 26 when 'Zaohong' was used as a hybrid male parent. Therefore, 'Zaohong' $\times$ 'Xiyeqing' and 'Xiyeqing' $\times$ 'Zaohong' possessing different fruit sets were 0 and $12.38 \%$, respectively, i.e., 'Zaohong' $\times$ 'Xiyeqing' displayed cross-incompatibility, but 'Xiyeqing' $\times$ 'Zaohong' showed cross-compatibility.

\section{S-RNase and SFB alleles from 'Zaohong'}

Two DNA bands were obtained from 'Zaohong' using the primer pair Pru-C2 and PCE-R (Fig. 1, S-RNase). Further cloning and sequencing confirmed that the $S$-genotype of 'Zaohong' was $S_{2} S_{15}$, the same as the identification by Xu et al. [32].

PCR amplification of the $S F B$ alleles was performed using the primer pair SFB-C1F and $\mathrm{Pm}-\mathrm{Vb}$, designed from conserved regions in the F-box motif and upstream of $\mathrm{HVb}$ of Prunus SFB genes, respectively. Only one amplified fragment of approximately $1,000 \mathrm{bp}$ was obtained from 'Zaohong' genomic DNA (Fig. 1 SFB). However, sequencing results showed that the band contained two different sequences, indicating the presence of two $S F B$ alleles in 'Zaohong'. Sequence analysis and BLAST searches in GenBank confirmed that two PmSFB genes, $\mathrm{PmSFB}_{2}$ (GenBank accession number: JQ356589) and $P m S F B_{15}$, were identified in 'Zaohong'.

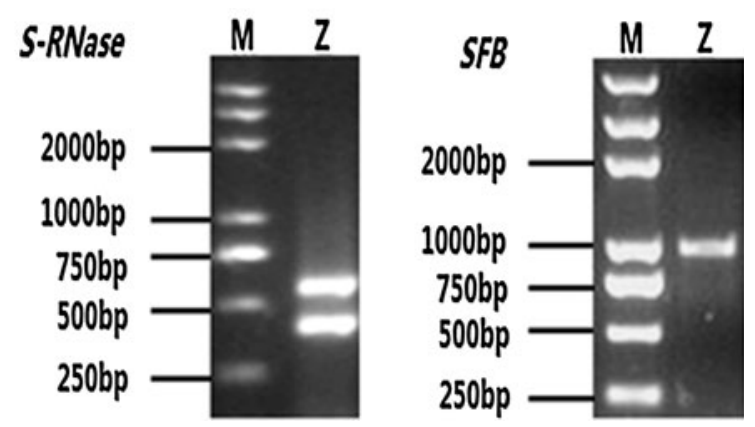

(L). $M$ is DNA marker, $Z$ is Zaohong and $G$ is genomic DNA. $a$ RTPCR of $S$-RNase alleles. $b$ RT-PCR of $S F B$ alleles. $c$ RT-PCR of PmF-box alleles. $d$ RT-PCR of Actin genes

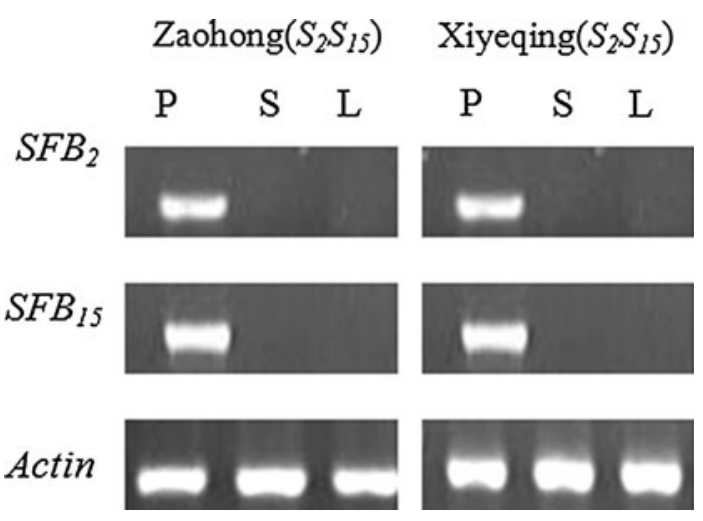

Fig. 2 RT-PCR analysis of the $S F B_{2}, S F B_{15}$ and Actin genes in pollen $(P)$, styles $(S)$ and leaves $(L)$ of 'Zaohong' $\left(S_{2} S_{15}\right)$ and 'Xiyeqing' $\left(S_{2} S_{15}\right)$

Specific expression of $S$-RNase and $S F B$ genes

RT-PCR of S-RNase, SFB and Actin genes was performed using total RNA from pollen grains, styles and leaves of 'Zaohong' with the primers Pru-C2/PCE-R, SFB-C1F/Pm$\mathrm{Vb}$ and ActF1/ActR1, respectively (Fig. 1). RT-PCR analysis of Actin genes amplified fragments of the same size, and which were shorter than the fragments amplified from genomic DNA, due to the absence of introns (Fig. 1d). The results, therefore, confirmed that the RNA preparations were free from genomic DNA contamination. For RT-PCR of $S$-RNase alleles, amplified fragments were only found in stylar RNA and genomic DNA (Fig. 1a). Furthermore, amplified fragments from the style were shorter those from genomic DNA due to the absence of the second intron. RTPCR of $S F B$ alleles from pollen grain RNA however, produced a fragment of the same size as that of genomic DNA, but no amplification was seen with leaf RNA or stylar RNA samples (Fig. 1b). Together, these results indicate that the $S$-RNase and $S F B$ alleles identified in 'Zaohong' are specifically expressed in style and pollen, respectively (Fig. 2). 
Fig. 3 Alignment of the predicted amino acid sequences of PmS-RNase alleles. Asterisks, dots and dashes indicate conserved amino acid residues, conservative substitutions and gaps, respectively. Conserved $(C 1, C 2, C 3, R C 4$ and $C 5)$ and hypervariable $(R H V)$ regions are boxed, and arrows indicate the position of the introns. GenBank accession numbers: $P m S_{1}$ (AB364462). $P m S_{2}$ and $P m S_{15}$ were determined in this study
PmS1

PmS2

PmS15

PmS1

PmS2

PmS15

PmS1

PmS2

PmS15
LAFLVLAFAFVCFIMSTGDGSDYFQFVQWP PTCRVRGKCSNPRPIQIFTIHGLWPS YSN LAFLVLGF AFFFCYYMSS--GS IDYFQFVQQWP TTHCRVRTKCSKPRPLQMTTIHGLWPS WSN LAFLVLAFAFFLCFIMSTGDGS DYFQFVQQWPPTHCRVRTKCSNPRPLQYFTIHGLWPS WSN

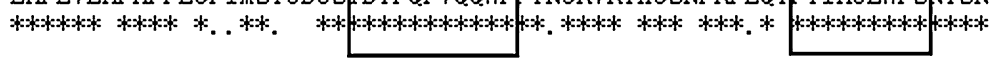

C1

C2
PTTPSNCIGEQFKESMVSPRLR RLKRSWPNEGSNDTHFWEGEWNKHGRCS DQTLNQYQYFER PTMPSNCNG SQFDARKVSPQLRNKLKRSWPDVESGNDTK FWEGEWNHGTCSEQTLNQFQYFER PKMPSNCIG PQFNESRVYPYLRHKLKISWPDVESGNDTHFWEGEWNHGTCSERILNQMQYFQR 128

\section{RHV}

C4

SHEMWHFHITNILKNASIVP PPTQTWTYSDIVSTIKAVTQTTPLVRCKQH KKTQLLHEVVC SQDMWRS INITEILKNASIVP SATQTWTYSDIVAPIKTATKRTPLLRCKYDKKTQLLHEVVXX SQANCWKSENISEILKNASIVP PPTQTWTYSDIVSPIKTATKRTPLLRCKYDKKTQLLHEVVLX

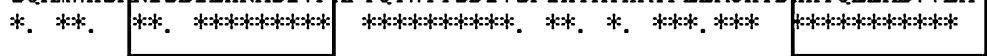
RC4

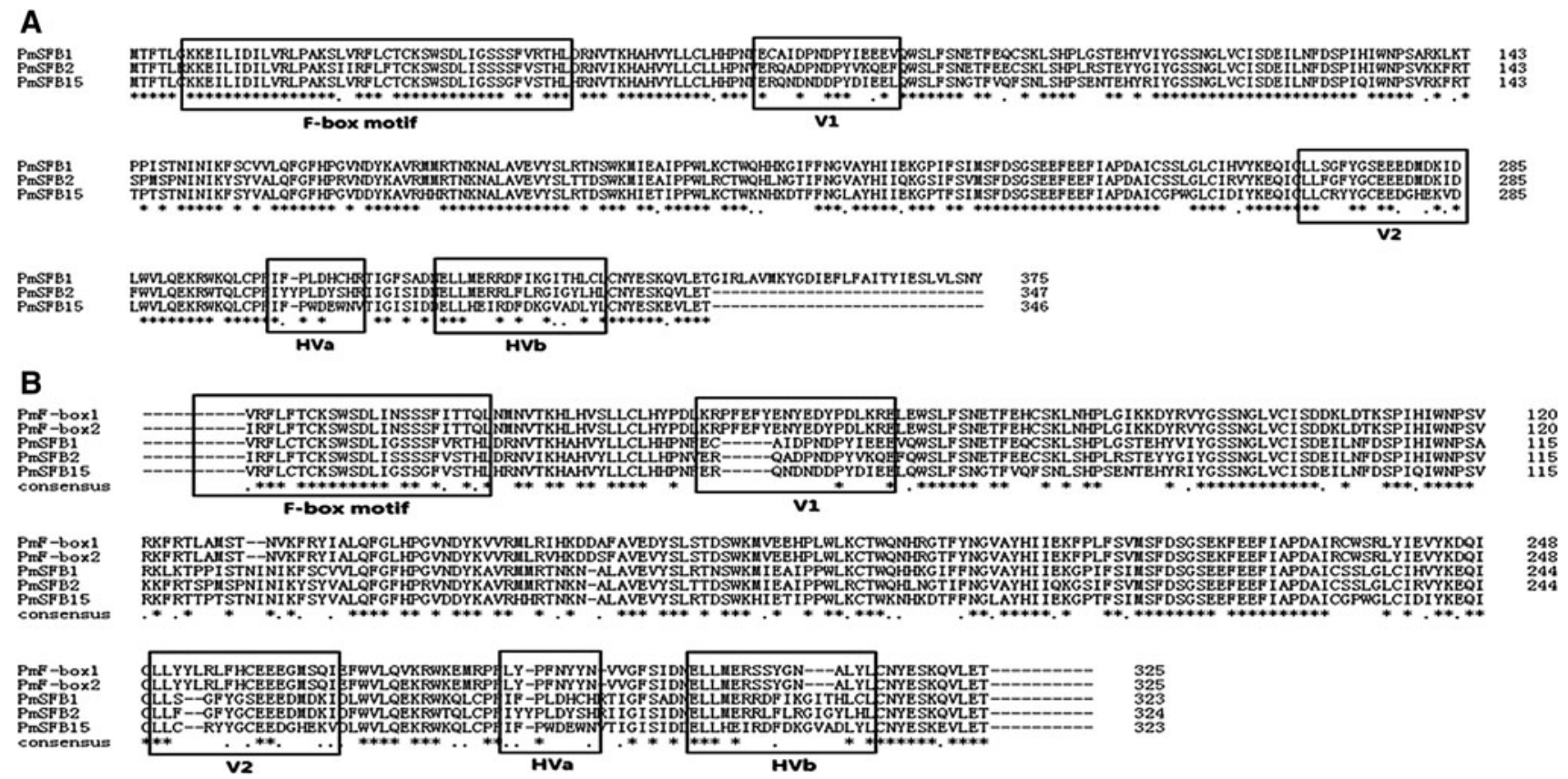

Fig. 4 a Alignment of the predicted amino acid sequences of $P m S F B$ alleles. b Alignment of the predicted amino acid sequences of $P m F$ box genes, $\mathrm{PmSFB}_{1}, \mathrm{PmSFB}_{2}$ and $\mathrm{PmSFB}_{15}$. F-box motif, variable $(V 1$ and $V 2)$ and hypervariable $(H V a$ and $H V b)$ regions are boxed.

Sequence analysis of $S$-RNase and $S F B$ genes

Using the primer pair, Pru-C2 and PCE-R, we confirmed that the $S$-genotype of 'Zaohong' was $S_{2} S_{15}$ based on sequence analysis. To analyse further the structure of $S$ RNase alleles, we cloned PCR products of almost fulllength sequences of $S$-RNase genes that contained the first and second introns, using SRc-F and PM-C5. These primers were designed from the signal peptide and the fifth conserved region of Prunus S-RNase genes, respectively. $S_{2}$-RNase and $S_{15}$-RNase were successfully cloned using $\mathrm{SRc}-\mathrm{F}$ and PM-C5. Compared with the predicted amino
GenBank accession numbers: $\mathrm{PmSFB}_{1}$ (AB101440). $\mathrm{PmSFB}_{2}$ and $P m S F B_{15}$ were determined in this study. Asterisks, dots and dashes indicate conserved amino acid residues, conservative substitutions and gaps, respectively

acid sequence of $P m S_{1}$-RNase, the putative $S_{2}$-RNase and $S_{15}$-RNase genes showed the typical features of Prunus $S$ RNase genes with five conserved domains $(\mathrm{C} 1, \mathrm{C} 2, \mathrm{C} 3$, $\mathrm{RC} 4$ and C5) and one RHV (Fig. 3). These results indicated that there were no mutations or insertions in $S_{2^{-}}$ RNase and $S_{15}$-RNase which could disrupt the typical features.

To analyse the structure of the PmSFB genes, PCRs were performed using F-BOX5 $5^{\prime} \mathrm{A}$ and $\mathrm{Pm}-\mathrm{Vb}$. As with $\mathrm{PmSFB}_{1}, \mathrm{PmSFB}_{2}$ and $P m S F B_{15}$ of 'Zaohong' were found to have an F-box motif and four (hyper-) variable regions (V1, V2, HVa and HVb) (Fig. 4a). Because the corss- 


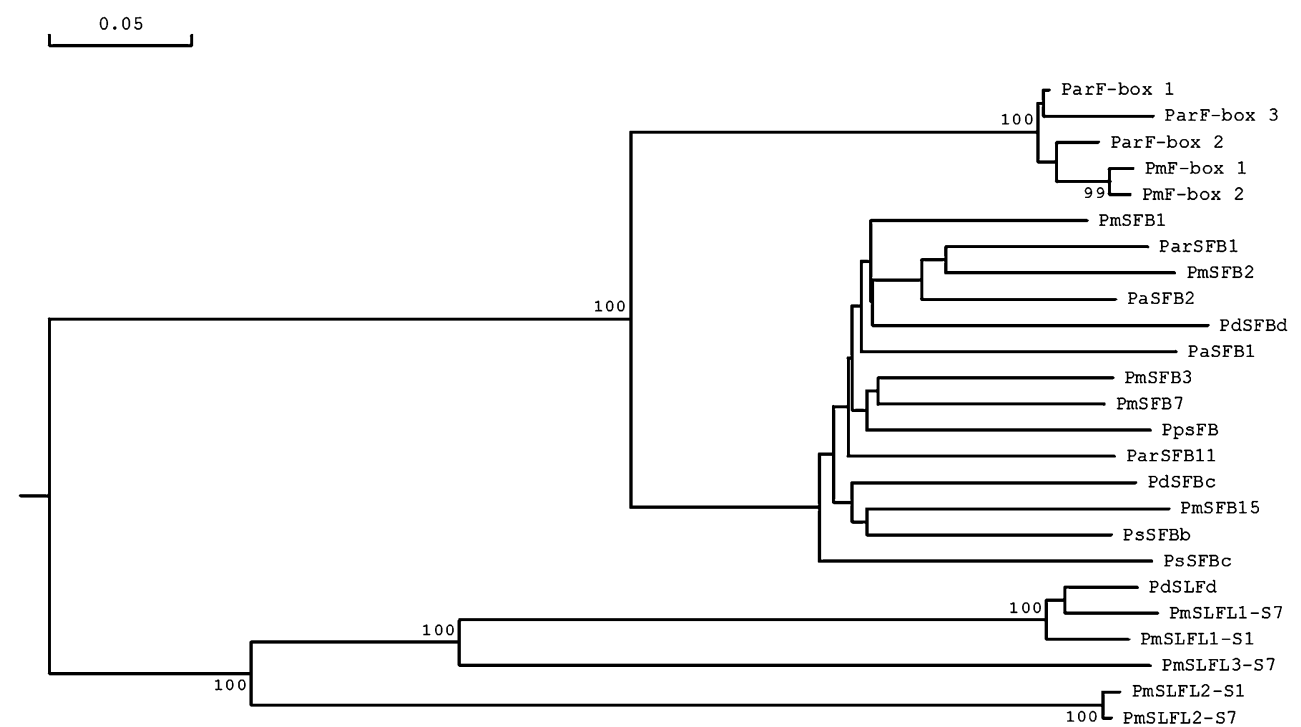

Fig. 5 Phylogenetic tree of $25 S F B / S L F(L)$ and $F$-box genes in GSI plants based on aligned amino acid sequences using neighbor-joining. The scale bar represents 0.05 substitutions per amino acid site. The numbers at each branch indicate the percentage of 1,000 bootstrap replicates supporting the grouping at that node. GenBank accession numbers: $\mathrm{PaSFB}_{1}$ (AY805048), $\mathrm{PaSFB}_{2}$ (AY805049), ParS$F B_{1}$ (AY587563), ParSFB ${ }_{11}$ (EU652884), PdSFB $B_{c}$ (AB079776), $\mathrm{PdSFB}_{d}$ (AB081648), PpsFB (HM347516), $\mathrm{PSSFB}_{b}$ (AB252412),

pollination tests indicated that SC in 'Zaohong' occurred in pollen, the specific expression of $S F B$ genes was tested using RT-PCR. Figure 2 showed that $S F B$ genes of 'Zaohong' have the same expression levels in pollen as $S F B$ genes of 'Xiyeqing'. Taken together, these findings indicate that neither the coding sequence nor the transcriptional level is altered in SFB genes of 'Zaohong'.

\section{Sequence analysis of PmF-box genes}

PmF-boxl (GenBank accession number: JX141276) and PmF-box2 (GenBank accession number: JX141277), which are $98.46 \%$ identical at the amino acid level, were identified from 'Zaohong' using SFB-C1F and Pm-Vb primers. The amino acid identities between $P m S F B$ and the $P m F$ box genes ranged from 61.03 to $64.65 \%$ (not shown). Interestingly, BLAST searches in GenBank showed that the amino acid sequences of PmF-box genes have a high similarity to ParF-box2 (95.69\%). Similar to the structure of PmSFB genes, both PmF-box genes contain a putative F-box motif, two variable regions (V1 and V2) and two hypervariable regions ( $\mathrm{HVa}$ and $\mathrm{HVb}$ ) (Fig. 4b). Despite this, there were several notable differences between the regions of PmF-box and PmSFB. Firstly, two insertions of either five or two amino acid residues exist in the regions of $P m F$-box genes, that correspond to the PmSFB variable V1 and V2 domains, respectively. Secondly, a deletion of three amino acid residues was found in the putative region of
PsSFB $_{c}$ (AB280792), PmSFB $_{1}$ (AB101440), PmSFB 3 (AB376968), $\mathrm{PmSFB}_{7}$ (AB101441), PmSLFL1-S1 (AB092623), PmSLFL1-S7 (AB092624), PmSLFL2-S1 (AB092625), PmSLFL2-S7 (AB092626), PmSLFL3-S7 (AB092627), PdSLF ${ }_{d}$ (AB101660), ParF-boxl (DQ422943), ParF-box2 (DQ422944) and ParF-box3 (DQ422945), the accession numbers of $\mathrm{PmSFB}_{2}, \mathrm{PmSFB}_{15}$ and two PmF-box genes were detailed in the text

PmF-box genes, corresponding to $\mathrm{HVb}$ in PmSFB genes. Lastly, the HVa domain in PmF-box genes had a deletion of one amino acid when compared with $P m S F B$ genes (Fig. 4b). RT-PCRs for PmF-box genes were performed with cDNAs from pollen grains, leaves and styles of 'Zaohong', using the specific primers PmF1 and PmF2 (Fig. 1c). The results from these PCRs showed that PmFbox genes are expressed not only in pollen, but also in leaves and styles.

Phylogenetic analysis

A rooted phylogenetic tree of 25 genes including $S F B /$ $S L F(L)$ and $F$-box genes in GSI plants was constructed using aligned amino acid sequences by the neighbourjoining method (Fig. 5). Two major classes, the $S F B$ clade and the $S L F(L)$ clade, were found in the phylogenetic tree which demonstrate that $S F B / S L F(L)$ and $F$-box genes share a common ancestor in Prunus. The tree also suggests that pollen determinant $S L F(L)$ genes likely diverged earlier in $S$-RNase-based SI evolution.

PmF-box genes were clustered together with ParF-box genes and away from the $S L F / S L F L$ genes, and appeared to be a sister group to the other Prunus $S F B$ gene clade (Fig. 5). These findings indicate that PmF-box genes are not $S F B$-like genes but are instead a novel type of F-box gene with a higher sequence similarity to $S F B$ than to $S L F$ / SLFL. 


\section{Discussion}

PmF-box, a novel F-box gene with sequence similarity to $S F B$ alleles

A novel type of F-box gene (PmF-boxl and PmF-box2) with sequence similarity to $S F B$ was identified in 'Zaohong'. The amino acid identities between PmF-box and $P m S F B$ genes ranged from 61.03 to $64.65 \%$, similar to those between PaF-box and ParFB described by Vilanova et al. [25]. A putative F-box motif, two variable regions (V1 and V2) and two hypervariable regions (HVa and $\mathrm{HVb}$ ) were identified in both PmF-box genes (Fig. 4b). The F-box motif, which contained many conserved residues, had previously been shown to be under purifying selection, and is essential for the formation of the SCF complex and subsequent protein degradation by the ubiquitin/26S proteasome pathway [41]. Meanwhile, V1, V2 and HVb of $S F B$ have been shown to be hydrophilic and under positive selection, and might be the regions responsible for discrimination between self and non-self S-RNases [25, 42]. Thus, it seems that whatever is the role of PmF-box proteins, functions related to these putative domains could be changed or lost with regard to SFB proteins. In comparison to $P m S F B$ genes, insertions and deletions were found in the putative regions $\mathrm{V} 1$ and $\mathrm{V} 2$, and $\mathrm{HVa}$ and $\mathrm{HVb}$ of $P m F$ box genes, respectively. These altered domains in PmF-box genes correspond to regions which are involved by $S F B$ proteins in the specific recognition of the style counterpart, which might result in PPM in SC cultivars. Moreover, phylogenetic analysis suggests that this new type of F-box gene might play a novel, important role in the mechanism of GSI.

In summary, PmF-box was identified as a novel type of F-box gene. Further research into these genes could provide a deeper understanding of self and non-self recognition mechanisms in GSI as well as in various aspects of plant growth and development at the molecular level.

$S$-locus external modifier factors might be involved in SC of 'Zaohong'

In most Prunus fruit trees, SC is attributed to loss of function of style or pollen $S$ genes. SPMs and PPMs have been shown to be associated with deletions or insertions in $S$ alleles. In this study, we confirmed SC of 'Zaohong' and SI of 'Xiyeqing', through self-pollination tests based on averaged data collected over a 3-year survey. Cross-pollination tests were also carried out to study SC in 'Zaohong' using 'Xiyeqing', the SI cultivar with same $S$ haplotypes $\left(S_{2} S_{15}\right)$. 'Zaohong' $\times$ 'Xiyeqing' displayed cross-incompatibility, but 'Xiyeqing' $\times$ 'Zaohong' showed cross- compatibility. Thus, the growth of pollen tubes of 'Xiyeqing' with the $S_{2}$ or $S_{15}$ haplotype was arrested in styles of 'Zaohong'. However, the growth of pollen tubes of 'Zaohong' was not arrested when growing in 'Xiyeqing' styles, showing that SC in 'Zaohong' occurred in pollen, not in styles.

Using SRc-F/PM-C5 and F-BOX5'A/Pm-Vb, S-haplotypes were successfully cloned. No mutations leading to SC of 'Zaohong' were found in $S$-haplotypes. To investigate the loss of function of pollen $S$ genes, the specific expression of $S F B$ genes was tested in 'Zaohong' and 'Xiyeqing'. The conclusion was that $S F B$ genes of 'Zaohong' have a similar expression in pollen to that of $S F B$ genes of 'Xiyeqing'. Taken together, these findings indicate that the loss of function of pollen $S$ genes causes SC of 'Zaohong', which is unrelated to both the mutation of the coding sequence and to the transcriptional level.

In addition to SPM and PPM, SC was also found to be associated with mutations at a modifier locus that is unlinked to the $S$-locus in Prunus. Indeed, Wünsch and Hormaza [24] and Wünsch et al. [27] have reported that the pollen-S component of the SC sweet cherry 'Cristobalina' is affected by a factor unlinked to the $S$-locus. In apricot meanwhile, Vilanova et al. [25] have also described a modifier locus affecting the function of the pollen $S$ factor in the cultivar 'Canino', while Wu et al. [28] similarly found that unlinked factors caused a loss in pollen $S$ activity in the cultivar 'Katy'. In almond, a modifier locus affecting the expression of the $S$-RNase gene might be the cause of the breakdown of SI [26].

In the Solanaceae, an alternative means to SC has been demonstrated, where duplications of an $S$-allele led to competitive interactions that ultimately resulted in PPMs $[6,43,44]$. In addition, $S$-heteroallelic pollen is the cause of self-compatibility in some Petunia tetraploids [45]. Japanese apricot is a diploid species [46] and, with the exception of the PmF-box genes, there are no duplications of either $S$-locus gene in 'Zaohong'. Vilanova et al. [25] rejected the possibility that SC in apricot, 'Canino' was due to $P a r F B S F B$-like genes acting as duplicated pollen$S$ genes. However, this mechanism might still be involved in the SC of Prunus, as expression of these genes in pollen (or tubes) is observed, as well as changes in putative domains that correspond to regions of $S F B$ proteins involved in the specific recognition of the style counterpart. Therefore, it appears that the loss of function of pollen $S$ genes of 'Zaohong' is not tightly linked to the $S$-locus. However, modifier factors outside the $S$-locus, including the PmF-box genes, might be associated with SC of 'Zaohong'.

Acknowledgments We gratefully acknowledge financial support for this research from the National Natural Science Foundation of 
China (31101526), Jiangsu Province Science Technology Independent Innovation Fund [CX(12)2011] and the Priority Academic Program Development of Jiangsu Higher Education Institutions (PAPD) for funding part of this study.

Open Access This article is distributed under the terms of the Creative Commons Attribution License which permits any use, distribution, and reproduction in any medium, provided the original author(s) and the source are credited.

\section{References}

1. Anderson MA, Cornish EC, Mau SL, Williams EG, Hoggart R, Atkinson A, Bonig I, Grego B, Simpson R, Roche PJ, Haley JD, Penschow JD, Niall HD, Tregear GW, Coghlan JP, Crawford RJ, Clarke AE (1986) Cloning of cDNA for a stylar glycoprotein associated with expression of self-incompatibility in Nicotiana alata. Nature 321:38-44

2. McClure BA, Haring V, Ebert PR, Anderson MA, Simpson RJ, Sakiyama F, Clarke AD (1989) Style self-incompatibility gene products of Nicotiana alata are ribonucleases. Nature 342:955-957

3. Xue Y, Carpenter R, Dickinson HG, Coen ES (1996) Origin of allelic diversity in Antirrhinum $S$ locus RNases. Plant Cell 8:805-814

4. Sassa H, Hirano H, Ikehashi H (1992) Self-incompatibility-related RNases in the styles of Japanese pear (Pyrus serotina Reid.). Plant Cell Physiol 33:811-814

5. Sassa H, Hirano H, Nishio T, Koba T (1997) Style-specific selfcompatible mutation caused by deletion of the S-RNase gene in Japanese pear (Pyrus serotina). Plant J 12:223-227

6. de Nettancourt D (2001) Incompatibility and incongruity in wild and cultivated plants. Springer, Berlin

7. Lai Z, Ma W, Han B, Liang L, Zhang Y, Hong G, Xue Y (2002) An F-box gene linked to the self-incompatibility $(S)$ locus of Antirrhinum is expressed specifically in pollen and tapetum. Plant Mol Biol 50:29-42

8. Entani T, Iwano M, Shiba H, Che FS, Isogai A, Takayama S (2003) Comparative analysis of the self-incompatibility $(S$-) locus region of Prunus mume: identification of a pollen-expressed F-box gene with allelic diversity. Genes Cells 8:203-213

9. Ushijima K, Sassa H, Dandekar AM, Gradziel TM, Tao R, Hirano $\mathrm{H}$ (2003) Structural and transcriptional analysis of the selfincompatibility locus of almond: identification of a pollenexpressed F-box gene with haplotype-specific polymorphism. Plant Cell 15:771-781

10. Sijacic P, Wang X, Skirpan AL, Wang Y, Dowd PE, McCubbin AG, Huang S, Kao TH (2004) Identification of the pollen determinant of $S$-RNase-mediated self-incompatibility. Nature 429:302-305

11. Huang S, Lee HS, Karunanandaa B, Kao TH (1994) Ribonuclease activity of Petunia inflata $S$ proteins is essential for rejection of self-pollen. Plant Cell 6:1021-1028

12. Ushijima K, Yamane H, Watari A, Kakehi E, Ikeda K, Hauck NR, Iezzoni AF, Tao R (2004) The $S$ haplotype-specific F-box protein gene, $S F B$, is defective in self-compatible haplotypes of Prunus avium and P. mume. Plant J 39:573-586

13. Qiao H, Wang F, Zhao L, Zhou J, Lai Z, Zhang Y, Robbins TP, Xue Y (2004) The F-box protein AhSLF-S2 controls the pollen function of $S$-RNase-based self-incompatibility. Plant Cell 16:2307-2322

14. Wang Y, Tsukamoto T, Yi KW, Wang X, Huang S, McCubbin AG, Kao TH (2004) Chromosome walking in the Petunia inflata self-incompatibility $(S$-) locus and gene identification in an 881-kb contig containing $S_{2}$-RNase. Plant Mol Biol 54:727-742
15. Minamikawa M, Kakui H, Wang S, Kotoda N, Kikuchi S, Koba T, Sassa H (2010) Apple $S$ locus region represents a large cluster of related, polymorphic and pollen-specific F-box genes. Plant Mol Biol 74:143-154

16. Yu P, Chen XS, Meng QW, Zheng Y, Shen X, Chen XL (2010) Three nonfunctional $S$-haplotypes in self-compatible tetraploid Chinese cherry (Prunus pseudocerasus L. cv. Taixiaohongying). Euphytica 174:143-151

17. Tao R, Watari A, Hanada T, Habu T, Yaegaki H, Yamaguchi M, Yamane H (2007) Self-compatible peach (Prunus persica) has mutant versions of the $S$ haplotypes found in self-incompatible Prunus species. Plant Mol Biol 63:109-123

18. Ushijima K, Sassa H, Tamura M, Kusaba M, Tao R, Gradziel TM, Dandekar AM, Hirano H (2001) Characterization of the $S$-locus region of almond (Prunus dulcis): analysis of a somaclonal mutant and a cosmid contig for an $S$ haplotype. Genetics 158:379-386

19. Tsukamoto T, Hauck NR, Tao R, Jiang N, Iezzoni AF (2006) Molecular characterization of three non-functional $S$-haplotypes in sour cherry (Prunus cerasus). Plant Mol Biol 62:371-383

20. Okada K, Tonaka N, Moriya Y, Norioka N, Sawamura Y, Matsumoto T, Nakanishi T, Takasaki-Yasuda T (2008) Deletion of a $236 \mathrm{~kb}$ region around $S_{4}$-RNase in a stylar-part mutant $S_{4}^{s m}$-haplotype of Japanese pear. Plant Mol Biol 66:389-400

21. Sonneveld T, Tobutt KR, Vaughan SP, Robbins TP (2005) Loss of pollen-S function in two self-compatible selections of Prunus avium is associated with deletion/mutation of an $S$ haplotypespecific F-box gene. Plant Cell 17:37-51

22. Marchese A, Bošković RI, Caruso T, Raimondo A, Cutuli M, Tobutt KR (2007) A new self-compatibility haplotype in the sweet cherry 'Kronio', $S_{5}$ ', attributable to a pollen-part mutation in the $S F B$ gene. J Exp Bot 5:4347-4356

23. Yamane H, Fukuta K, Matsumoto D, Hanada T, Mei G, Esumi T, Habu T, Fuyuhiro Y, Ogawa S, Yaegaki H, Yamaguchi M, Tao R (2009) Characterization of a novel self-compatible $S^{3^{\prime}}$ haplotype leads to the development of a universal PCR marker for two distinctly originated self-compatible $S$ haplotypes in Japanese apricot (Prunus mume Sieb. et Zucc.). J Jpn Soc Hortic Sci 78:40-48

24. Wünsch A, Hormaza JI (2004) Genetic and molecular analysis in Cristobalina sweet cherry, a spontaneous self-compatible mutant. Sex Plant Reprod 17:203-210

25. Vilanova S, Badenes ML, Burgos L, Martinez-Calvo J, Llacer G, Romero C (2006) Self-compatibility of two apricot selections is associated with two pollen-part mutations of different nature. Plant Physiol 142:629-641

26. Fernández i Martí A, Hanada T, Alonso JM, Yamane H, Tao R, Company RS (2009) A modifier locus affecting the expression of the $S$-RNase gene could be the cause of breakdown of selfincompatibility in almond. Sex Plant Reprod 22:179-186

27. Wünsch A, Tao R, Hormaza JI (2010) Self-compatibility in 'Cristobalina' sweet cherry is not associated with duplications or modified transcription levels of $S$-locus genes. Plant Cell Rep 29:715-721

28. Wu J, Gu C, Du YH, Wu HQ, Liu WS, Liu N, Lu J, Zhang SL (2011) Self-compatibility of 'Katy' apricot (Prunus armeniaca L.) is associated with pollen-part mutations. Sex Plant Reprod 24:23-35

29. Miyake M, Yamaguchi M, Haji T (1995) The self-compatibility in mume cultivars (in Japanese). J Jpn Soc Hortic Sci 64(suppl. 2):116-117

30. Tao R, Habu T, Yamane H, Sugiura A, Iwamoto K (2000) Molecular markers for self-compatibility in Japanese apricot (Prunus mume). HortScience 35:1121-1123

31. Yaegaki H, Shimada T, Moriguchi T, Hayama H, Haji T, Yamaguchi M (2001) Molecular characterization of $S$-RNase genes and $S$-genotypes in the Japanese apricot (Prunus mume Sieb. et Zucc.). Sex Plant Reprod 13:251-257 
32. Xu JX, Gao ZH, Zhang Z (2010) Identification of S-genotypes and novel $S$-RNase alleles in Japanese apricot cultivars native to China. Sci Hortic 123:459-463

33. Wang FR, Tong ZG, Zhang Z, Chen HQ, Jiang LJ, Zhao JB (2006) Study on improvement of DNA extraction method using tender leaves of wild peach (in Chinese). J Agric Sci 5:66-69

34. Tao R, Yamane H, Sugiura A, Murayama H, Sassa H, Mori H (1999) Molecular typing of $S$-alleles through identification, characterization and cDNA cloning for $S$-RNases in sweet cherry. J Am Soc Hortic Sci 124:224-233

35. Yamane H, Tao R, Sugiura A, Hauck NR, Iezzoni AF (2001) Identification and characterization of $S$-RNases in tetraploid sour cherry (Prunus cerasus). J Am Soc Hortic Sci 126:661-667

36. Vilanova S, Romero C, Llacer G, Badenes ML, Burgos L (2005) Identification of self-(in)compatibility alleles in apricot by PCR and sequence analysis. J Am Soc Hortic Sci 130:893-898

37. Habu T, Matsumoto D, Fukuta K, Esumi T, Tao R, Yaegaki H, Yamaguchi M, Matsuda M, Konishi T, Kitajima A, Yamada T (2008) Cloning and characterization of twelve $S$-RNase alleles in Japanese apricot (Prunus mume Sieb. et Zucc.). J Jpn Soc Hortic Sci 77:374-381

38. Xu JX, Gao ZH, Hou JH, Wang S, Zhang Z (2008) Optimization of AS-PCR analysis system of Japanese apricot (Prunus mume Sieb. et Zucc) (in Chinese). J Agric Sci 2:69-71

39. Vaughan SP, Russell K, Sargent DJ, Tobutt KR (2006) Isolation of $S$-locus F-box alleles in Prunus avium and their application in a novel method to determine self-incompatibility genotype. Theor Appl Genet 112:856-866

40. Yamane H, Ushijima K, Sassa H, Tao R (2003) The use of the $S$ haplotype-specific F-box protein gene, $S F B$, as a molecular marker for $S$-haplotypes and self-compatibility in Japanese apricot (Prunus mume). Theor Appl Genet 107:1357-1361

41. Deshaies RJ (1999) SCF and cullin/RING H2-based ubiquitin ligases. Annu Rev Cell Dev Biol 15:435-467

42. Ikeda K, Igic B, Ushijima K, Yamane H, Hauck NR, Nakano R, Sassa H, Iezzoni AF, Kohn JR, Tao R (2004) Primary structural features of the $S$ haplotype-specific F-box protein, $S F B$, in Prunus. Sex Plant Reprod 16:235-243

43. Brewbaker JL, Natarajan AT (1960) Centric fragments and pollen part mutation of in-compatibility alleles in Petunia. Genetics 45:699-704

44. Golz JF, Oh HY, Su V, Kusaba M, Newbigin E (2001) Genetic analysis of Nicotiana pollen-part mutants is consistent with the presence of an $S$-ribonuclease inhibitor at the $S$ locus. Proc Natl Acad Sci USA 98:15372-15376

45. Stout AB, Chandler C (1941) Change from self-incompatibility to self-compatibility accompanying change from diploidy to tetraploidy. Science 94:118

46. Chu MY (1999) China fruit records-Mei. China Forestry, Beijing 